\title{
Reply from the Author
}

\section{抗 N-methyl-D-aspartate（NMDA）受容体脳炎後に発症した 薬剤抵抗性てんかんに対して，緩和的外科的治療が有用であった 2 症例}

\author{
小澤 明子1) 山崎 峰雄 1 ** 戸田 諭輔1) \\ 江畑 环也 ${ }^{1}$ ～峯 清一郎 ${ }^{2}$ 木村 和美 ${ }^{3)}$
}

\section{Successful palliative surgical treatment for drug-resistant epilepsy after anti-N-methyl-D-aspartate (NMDA) receptor encephalitis: Two case reports}

Akiko Ozawa, M.D. ${ }^{1)}$, Mineo Yamazaki, M.D., Ph.D. ${ }^{1)}$, Yusuke Toda, M.D., Ph.D. ${ }^{1}$, Takuya Ebata, M.D. ${ }^{1)}$, Seiichiro Mine, M.D., Ph.D. ${ }^{2)}$ and Kazumi Kimura, M.D., Ph.D. ${ }^{3)}$

1) Department of Neurology, Chiba Hokusoh Hospital

${ }^{2)}$ Division of Neurosurgery, Chiba Prefectural Sawara Hospital

(Present address: Epilepsy Center and Division of Neurosurgery, Gyotoku General Hospital)

${ }^{3)}$ Department of Neurology, Nippon Medical School

（臨床神経 2021;61:407-408）

\section{捃復}

私どもの論文「抗 N-methyl-D-aspartate（NMDA）受容体脳 炎後に発症した薬剂抵抗性てんかんに対して, 緩和的外科的 治療が有用であった 2 症例」1)に関して極めて重要なご指摘 をいただき，ありがとうございました。

この報告で私どもが最も主張したかった点は，自己免疫性 脳炎の範疇にある病態で, 難治性（薬剤抵抗性）てんかんを 合併した場合に，外科的治療を行うことによって，てんかん がコントロールされる症例が存在するので, 自己免疫性脳炎 では一般的ではないものの外科的治療をためらうべきではな いという点でありました.

しかし, 先生がご指摘の通り, 抗 NMDA 受容体脳炎の診断 に関して問題がありました。抗 NMDA 受容体脳炎は, GluN1 サブユニットのアミノ末端ドメイン上にある立体的エピトー プを認識する抗体によって生じる疾患であり ${ }^{2)}$, 診断は現在 検査会社でも実施可能となった cell-based assay での測定が必 要です，抗 NMDA 受容体抗体は，神経細胞のシナプス後膜に 発現する NMDA 受容体の立体構造に反応するため, 立体構造 を保持した受容体抗原が必要であり，そのために培養細胞表 面に生体内と同様の抗原構造を持つ受容体を発現させて測定 する cell-based assay が要求されます 3 .
ご指摘の通り，私どもが計測した ELISA 法による NMDA 受容体に対する抗体, 抗 GluRe2 抗体, Glu $\delta 2$ 抗体は個々のサ ブユニットを抗原として検出するもので，いわゆる「広義の 抗 NMDA 受容体抗体」であり ${ }^{4)}$, 上記の cell-based assay に より検出される抗体とは異なるものであります。今後はこの 「抗グルタミン酸受容体抗体陽性脳炎」と「抗 NMDA 受容体 脳炎」を明確に区別していきたいと存じます。先生におかれ ましては，診断に関しての重要なご指摘をいただき，ありが とうございました

敬具

※著者全員に本論文に関連し，開示すべきCOI 状態にある企業， 組織，団体はいずれも有りません。

\section{文献}

1）小澤明子, 山崎峰雄, 戸田諭輔ら。抗 N-methyl-D-aspartate （NMDA）受容体脳炎後に発症した薬剤抵抗性てんかんに対 して, 緩和的外科的治療が有用であった 2 症例. 臨床神経 2020;60:32-36.

2) Gleichman AJ, Spruce LA, Dalmau J, et al. Anti-NMDA receptor encephalitis antibody binding Is dependent on amino acid identity of a small region within the GluN1 amino terminal

*Corresponding author: 日本医科大学千葉北総病院脳神経内科〔 $\overline{\mathrm{T}}$ 270-1694 千葉県印西市鎌荻 1715〕

1) 日本医科大学千葉北総病院脳神経内科

2) 千葉循環器病センター脳神経外科 (現 : 行徳総合病院てんかんセンター脳神経外科)

3) 日本医科大学大学院医学研究科神経内科学分野

(Received January 14, 2021; Accepted January 30, 2021; Published online in J-STAGE on May 21, 2021)

doi: 10.5692/clinicalneurol.cn-001587 
domain. J Neurosci 2012;32:11082-11094.

3) Dalmau J, Armangue T, Planaguma J, et al. An update on antiNMDA receptor encephalitis for neurologists and psychiatrists: mechanisms and models. Lancet Neurol 2019;18:1045-1057.

4）高橋幸利, 高山留美子, 向田壮一ら. 抗 NMDA 受容体抗体 と抗グルタミン酸受容体 $\varepsilon 2$ 抗体. 最新医学 2009;64:26-32. 